DOI: $10.19195 / 0137-1134.114 .41$

\author{
MICHAŁ STRZELBICKI \\ Uniwersytet im. Adama Mickiewicza w Poznaniu \\ michalstrzelbicki@wp.pl
}

\title{
SKUTKI PRAWNE KONTROLI PRZEDSIĘBIORCY PROWADZONEJ Z NARUSZENIEM ZASAD KONTROLI
}

\begin{abstract}
Abstrakt: Wraz z wejściem w życie ustawy o swobodzie działalności gospodarczej w polskim publicznym prawie gospodarczym zaczęły obowiązywać przepisy zawarte w jej rozdz. 5 zatytułowanym Kontrola przedsiębiorcy. Istotą tej regulacji jest wprowadzenie zasad kontroli, to znaczy standardów, wedle których powinna przebiegać każda kontrola działalności gospodarczej przedsiębiorcy przez administrację. Poddanie kontroli przedsiębiorcy regulacji prawnej i ujęcie jej w ramy wyznaczające granice swobody organu kontroli w założeniu ustawodawcy miało ograniczyć naturalną przewagę organu nad przedsiębiorcą w toku prowadzenia czynności kontrolnych.

Ustawodawca zdawał sobie sprawę, że samo wprowadzenie zasad kontroli nie wystarczy, aby skutecznie chronić interesy przedsiębiorców. Z tego względu zabezpieczył przestrzeganie przez administrację zasad kontroli przedsiębiorców przez uregulowanie daleko idących, negatywnych dla organu skutków prawnych ich naruszenia. Przedmiotem analizy w niniejszym artykule są rozwiązania prawne dające przedsiębiorcy prawo do dochodzenia od państwa odszkodowania oraz pozwalające mu domagać się, aby zgromadzone w trakcie kontroli dowody nie mogły być następnie wykorzystywane przeciwko temu przedsiębiorcy przez administrację (są to tak zwane owoce zatrutego drzewa). Autor opracowania przedstawia zakres zastosowania obu tych instytucji oraz zajmuje stanowisko wobec związanych z nimi szczegółowych zagadnień, będących dotąd przedmiotem sporów w doktrynie i orzecznictwie.
\end{abstract}

Słowa kluczowe: kontrola przedsiębiorcy, zasady prowadzenia kontroli działalności przedsiębiorcy, odpowiedzialność odszkodowawcza państwa, zasada owocu zatrutego drzewa, ograniczenia wykorzystania nielegalnie zdobytych dowodów

Przypada mi w udziale zaszczyt opublikowania artykułu naukowego w księdze jubileuszowej dedykowanej Prof. Leonowi Kieresowi. W niniejszym artykule chciałbym nawiązać do dorobku, organizowanych cyklicznie od 2004 roku, wspólnych konferencji naukowych z udziałem pracowników i doktorantów kierowanego przez Jubilata Zakładu Publicznego Prawa Gospodarczego Uniwersytetu Wrocławskiego oraz Katedry Publicznego Prawa Gospodarczego Uniwersytetu im. 
Adama Mickiewicza w Poznaniu1. Problematyka poruszana podczas obrad, a także w późniejszych publikacjach koncentrowała się wokół węzłowych zagadnień nauki publicznego prawa gospodarczego, takich jak funkcje administracji gospodarczej, środki prawne, procedury publicznego prawa gospodarczego czy współdziałanie podmiotów publicznych i prywatnych w sferze gospodarki komunalnej. Moim zamiarem jest kontynuowanie rozważań zawartych w wygłoszonym przeze mnie podczas ostatniej konferencji ${ }^{2}$ referacie dotyczącym kontroli działań kontrolnych prowadzonych przez administrację u przedsiębiorcy ${ }^{3}$. Przedmiotem opracowania będą zatem skutki prawne prowadzenia kontroli przedsiębiorcy z naruszeniem zasad kontroli, to jest ograniczenia możliwości wykorzystania przeprowadzonych $\mathrm{w}$ toku kontroli dowodów oraz prawa przedsiębiorcy do odszkodowania.

Wraz z wejściem w życie ustawy o swobodzie działalności gospodarczej ${ }^{4}$ w polskim publicznym prawie gospodarczym zaczęły obowiązywać regulacje zawarte w jej rozdz. 5 zatytułowanym Kontrola przedsiębiorcy ${ }^{5}$. Według zamierzeń ustawodawcy przepisy rozdz. 5 usdg miały uzyskać charakter uniwersalnych standardów, mających co do zasady zastosowanie do wszystkich kontroli prowadzonych przez organy administracji publicznej u przedsiębiorców na podstawie różnych, szczególnych wobec usdg podstaw prawnych (art. 77 ust. 1-2 usg w pierwotnym brzmieniu) ${ }^{6}$. Poddanie kontroli przedsiębiorcy regulacji prawnej i ujęcie jej w ramy wyznaczające granice swobody organu kontroli w założeniu ustawo-

${ }^{1}$ O historii wspólnych konferencji naukowych zob. B. Popowska, Dedykacje i wspomnienia, [w:] Funkcje wspótczesnej admisnitracji gospodarczej. Księga dedykowana Profesor Teresie Rabskiej, red. B. Popowska, Poznań 2006, s. 5; L. Kieres, Wprowadzenie, [w:] Środki publicznego prawa gospodarczego, red. L. Kieres, Wrocław 2007, s. 9; K. Kiczka Wprowadzenie, „Przegląd Prawa i Admisnitracji” 98, 2014, s. 9-10.

2 Konferencja „Kontrola działań administracji publicznej w sferze gospodarki”, Poznań 29 września $2016 \mathrm{r}$.

${ }^{3}$ Referat pt. Kontrola kontroli przedsiębiorcy w świetle ustawy o swobodzie działalności gospodarczej, [w:] Kontrola działań administracji publicznej w sferze gospodarki, red. K. Kokocińska, Poznań 2018, s. 111.

${ }^{4}$ Ustawa z dnia 2 lipca 2004 r. o swobodzie działalności gospodarczej (tekst jedn. Dz.U. z 2017 r. poz. 2168 ze zm.; dalej: usdg).

5 Analogicznych rozwiązań nie zawierały wcześniejsze ustawy: z dnia 23 grudnia $1988 \mathrm{r}$. o działalności gospodarczej (Dz.U. z 1988 r. Nr 41, poz. 324 ze zm.) oraz z dnia 19 listopada 1999 r. — Prawo działalności gospodarczej (Dz.U. z 1999 r. Nr 101, poz. 1178 ze zm.).

${ }^{6}$ Por. także uzasadnienie projektu ustawy - Sejm RP IV kadencji, druk nr 2118, s. 50-51. Od 2009 r. ustawodawca wprowadził w tym obszarze derogację przepisów rozdz. 5 usdg odnośnie do kontroli prowadzonych na zasadach i w trybie wynikającym z prawa UE albo ratyfikowanych umów międzynarodowych; por. ustawa z dnia 19 grudnia 2008 r. o zmianie ustawy o swobodzie działalności gospodarczej oraz zmianie niektórych innych ustaw (Dz.U. z 2009 r. Nr 18, poz. 97) — jednocześnie w tej samej nowelizacji wprowadzono zmiany w blisko 50 ustawach szczególnych, polegające na poddaniu przewidzianych w nich kontroli przepisom usdg, co pozwoliło na dalsze ujednolicenie regulacji. Przyznanie rozdz. 5 usdg pierwszeństwa względem regulacji ustaw szczególnych spotkało się z krytyką w literaturze; por. C. Banasiński, M. Bychowska, Kontrola przedsiębiorcy w świetle ustawy o swobodzie działalności gospodarczej, „Przegląd Prawa Handlowego” 2010, nr 1, s. 48. 
dawcy miało ograniczyć naturalną przewagę organu nad przedsiębiorcą w toku prowadzenia czynności kontrolnych. Początkowo usdg zawierała jedynie kilka tak zwanych zasad kontroli, czyli standardów, wedle których przebiegać powinna co do zasady każda (jakkolwiek ze znaczną liczbą wyjątków) kontrola prowadzona u przedsiębiorcy ${ }^{7}$. Rozszerzenie katalogu zasad kontroli nastąpiło w związku z nowelizacją przepisów rozdz. 5 usdg na przełomie lat 2008/2009 ${ }^{8}$. Wówczas ustawodawca wprowadził również przepisy służące egzekwowaniu od organów kontroli przestrzegania wspomnianych zasad, to jest regulacje dotyczące skutków prawnych prowadzenia kontroli z naruszeniem postanowień rozdz. 5 usdg.

\section{OGRANICZENIA DOWODOWE}

Zgodnie z art. 77 ust. 6 usdg dowody przeprowadzone w toku kontroli przez organ kontroli z naruszeniem przepisów prawa w zakresie kontroli działalności gospodarczej przedsiębiorcy, jeżeli miały istotny wpływ na wyniki kontroli, nie mogą stanowić dowodu w żadnym postępowaniu administracyjnym, podatkowym, karnym lub karno-skarbowym dotyczącym kontrolowanego przedsiębiorcy. Niestety ramy niniejszego opracowania nie pozwalają na prowadzenie analizy teoretycznych podstaw unormowania zawartego w art. 77 ust. 6 usdg 9 . Wypada jednak zauważyć, że tak jasno wyrażone przez ustawodawcę ograniczenia dowodowe, sprowadzające się do eliminacji dowodu z uwagi na sam sposób jego pozyskania, w obecnym kształcie polskiej procedury cywilnej, karnej (po nowelizacji przepisu art. 168a k.p.k. ${ }^{10}$ )

7 Należały do nich pierwotnie: zasada prowadzenia kontroli na podstawie upoważnienia do jej przeprowadzenia (art. 79 usdg w pierwotnym brzmieniu), zasada kontroli w obecności przedsiębiorcy lub osoby przez niego upoważnonej (art. 80 usdg), zasada jednej kontroli w jednym czasie (art. 82 usdg) oraz zasada ograniczonego czasu trwania kontroli w roku (art. 83 usdg).

8 Ustawa z dnia 19 grudnia 2008 r. o zmianie ustawy o swobodzie działalności gospodarczej oraz zmiana niektórych innych ustaw (Dz.U. z 2009 r. Nr 18, poz. 97). Dodano wówczas zasady: kontroli po doręczeniu przedsiębiorcy zawiadomienia o zamiarze jej wszczęcia (art. 79 usdg), kontroli w siedzibie lub miejscu prowadzenia działalności kontrolowanego (art. 80a usdg), kontroli sprawnej i niezakłócającej działalności przedsiębiorcy (art. 80b usdg).

${ }^{9}$ Brzmienie art. 77 ust. 6 usdg można postrzegać jako nawiązanie do - mającej swe źródło w amerykańskiej procedurze karnej — zasady owocu zatrutego drzewa. W ten sposób art. 77 ust. 6 usdg postrzega także NSA; por. wyrok NSA z dnia 5 marca 2013 r., II OSK 2111/11, http:/orzeczenia.nsa.gov.pl/doc/4793F0194E. Na temat źródeł oraz formowania się zasady owocu zatrutego drzewa w orzecznictwie Sądu Najwyższego USA zob. np. P. Lech, Owoce zatrutego drzewa w procesie karnym. Dowody zdobyte nielegalnie, „Palestra” 2012, nr 3-4, s. 36 n.

10 Przepis art. 168a k.p.k. dodany został ustawą z dnia 27 września 2013 r. o zmianie ustawy — Kodeks postępowania karnego oraz niektórych innych ustaw (Dz.U. z 2013 r. poz. 1247) i wszedł w życie 1 lipca 2015 r., a następnie został gruntownie znowelizowany ustawą z dnia 11 marca $2016 \mathrm{r}$. o zmianie ustawy — Kodeks postępowania karnego oraz niektórych innych ustaw (Dz.U. z 2016 r. poz. 437). 
oraz administracyjnej nie są powszechne ${ }^{11}$. Przeciwnie, uprawniona wydaje się teza, że w żadnej ze wskazanych procedur nie ma obecnie równie daleko posuniętej regulacji chroniącej jednostkę przed skutkami pozyskania przez państwo dowodów w sposób niezgodny z prawem, jak ma to miejsce w wypadku ochrony przedsiębiorców przed skutkami naruszenia zasad kontroli przez organ.

W doktrynie wyrażono pogląd, że wprowadzenie art. 77 ust. 6 usdg jest zbędne ze względu na treść art. $156 \S 1$ pkt 2 k.p.a., nakazującego organowi stwierdzenie nieważności decyzji, jeśli została ona wydana z rażącym naruszeniem prawa. W konsekwencji, skoro podstawą stwierdzenia nieważności decyzji mogą być między innymi naruszenia norm procesowych, to naruszenie zasad kontroli, które doprowadziło do pozyskania dowodów, na podstawie których decyzja została wydana, skutkowałoby koniecznością zastosowania art. $156 \S 1$ pkt 2 k.p.a. i osiągnięciem tego samego celu co z zastosowaniem art. 77 ust. 6 usdg ${ }^{12}$. Stanowisko to wydaje się jednak dyskusyjne. Po pierwsze, zgromadzone w trakcie kontroli dowody mogą być wykorzystywane w rozmaitych postępowaniach, nie tylko w postępowaniu administracyjnym zwieńczonym wydaniem decyzji — wówczas z oczywistych względów przedsiębiorca nie byłby przepisem chroniony art. 156 k.p.a. Po drugie, nawet w zakresie wykorzystania dowodów w postępowaniu administracyjnym wypada zauważyć, że nie każde naruszenie zasad kontroli będzie można zakwalifikować jako rażące, uzasadniające zastosowanie art. 156 k.p.a. (traktującego przecież o stwierdzeniu nieważności decyzji) ${ }^{13}$. Z tych względów

11 W doktrynie wyrażono pogląd, że przejawów zasady owoców zatrutego drzewa nie należy przy tym dopatrywać się na przykład w przepisach k.p.k. formułujących tak zwane zakazy dowodowe, ponieważ stanowią ona zaledwie wyjątek od zasady prawdy materialnej; por. M. Lewandowski, Koncepcja , owoców zatrutego drzewa” a swobodna ocena dowodów w orzecznictwie sądów polskich i Europejskiego Trybunału Praw Człowieka, „Studia Prawa Publicznego” 2013, nr 2, s. 130. Pogląd, że w polskiej procedurze karnej nie obowiązuje zasada owoców zatrutego drzewa, jako niebudzący wątpliwości i to nawet w okresie obowiązywania art. 168a k.p.k. sprzed jego nowelizacji z 11 marca 2016 r. wyraził Sąd Najwyższy; por. wyrok SN z dnia 2 lutego 2016 r., IV KK 346/15, http://www. sn.pl/orzecznictwo; zob. także W. Hibner, Czy w polskim systemie prawnym obowiazuje zasada pozyskiwania dowodów z ,,owoców zatrutego drzewa”?, „Homines Hominibus” 2011, nr 7, s. 85 n. Zgodnie z kolei z art. 75 § 1 k.p.a. granicą dopuszczalności środków dowodowych w postępowaniu administracyjnym jest ich zgodność z przepisami prawa, którą należy interpretować w świetle regulacji w przepisach prawa materialnego, uwzględniając całokształt tej regulacji wyznaczającej hipotetyczny stan faktyczny; tak B. Adamiak, [w:] B. Adamiak, J. Borkowski, Kodeks postępowania administracyjnego. Komentarz, Warszawa 2017, s. 435.

12 C. Banasiński, M. Bychowska, op. cit., s. 49.

13 Jak podnosi NSA, „rażące naruszenie prawa jest to naruszenie tzw. kwalifikowane, o szczególnie dużym ciężarze gatunkowym, oczywiste, czyli takie, które stanowi zaprzeczenie stanu prawnego istotnego z punktu widzenia danego rozstrzygnięcia. Przy czym chodzi o stan prawny w zakresie jego obowiązywania i interpretacji niewątpliwy, niepozwalający i nierodzący rozbieżności w wykładni. Cechą rażącego naruszenia prawa jest to, że treść decyzji pozostaje w wyraźnej sprzeczności z treścią przepisu przez ich proste zestawienie ze sobą, przy czym nie chodzi tu o błędy w wykładni prawa, a o przekroczenie prawa w sposób jasny i niedwuznaczny" — wyrok NSA z dnia 18 maja 2017 r., I OSK 141/16, Legalis. „Przesłanki rażącego naruszenia prawa należy upatrywać nie w błę- 
należy uznać, że wprowadzenie art. 77 ust. 6 jest uzasadnione, a zawarta w nim regulacja nie dubluje ochrony prawnej przysługującej przedsiębiorcy na gruncie k.p.a., ale obszar tej ochrony rozszerza.

Zakres zastosowania ograniczenia dowodowego z art. 77 ust. 6 usg wyznaczony jest szeroko, ponieważ dyskwalifikacji podlegają dowody zdobyte wskutek każdego naruszenia prawa, bez względu na jego charakter czy stopień (ustawodawca nie ogranicza jej zastosowania na przykład tylko do naruszeń rażących) ${ }^{14}$. Teoretycznie więc każde naruszenie zasad kontroli w toku kontroli może być podstawą do dyskwalifikacji dowodu. Ważne jest jedynie, by naruszenie to dotyczyło unormowanych w rozdz. 5 usdg zasad kontroli i to w zakresie, w jakim nie zachodzi od nich żaden z licznych wyjątków.

Jednocześnie zasada ta została istotnie ograniczona, podmiotowo i przedmiotowo - na cztery sposoby. Po pierwsze, naruszenie przez organ w toku kontroli innych przepisów niż rozdz. 5 usdg nie wywoła skutku z art. 77 ust. 6 usdg. Po wtóre, dowody nie mogą być wykorzystane jedynie przeciwko temu przedsiębiorcy, podczas którego kontroli zostały zdobyte — nie ma jednak przeszkód, by wykorzystywać dowody przeprowadzone $\mathrm{z}$ naruszeniem prawa w postępowaniach dotyczących innych podmiotów, jak się wydaje, w tym na przykład powiązanych kapitałowo czy organizacyjnie, ale formalnie odrębnych. Po trzecie, ograniczenia dowodowe dotyczą wyliczonych w przepisie postępowań, wśród których brakuje choćby postępowania cywilnego ${ }^{15}$. Po czwarte wreszcie, dowody pozyskane z naruszeniem prawa muszą mieć istotny wpływ na wynik kontroli. Zwłaszcza ta ostatnia przesłanka jest silnie akcentowana w orzecznictwie sądów administra-

dach wykładni przepisu, lecz w jasnych i niedwuznacznych przekroczeniach prawa i to takich, które z uwagi na ich skutki powodują, że dotkniętego wadą rozstrzygnięcia nie da się pogodzić z panującym porządkiem prawnym. O tym, czy miało miejsce rażące naruszenie prawa, decyduje więc przede wszystkim oczywistość tego naruszenia prowadząca do nadania prawa lub odmowy jego przyznania wbrew wszystkim przesłankom przepisu" - wyrok WSA w Poznaniu z dnia 2 sierpnia 2017 r., IV SA/Po 243/17, Legalis. Rozumienie pojęcia „rażącego naruszenia prawa” nie jet zresztą jednolite, zarówno w literaturze, jak i orzecznictwie zarysowały się przynajmniej dwa jego ujęcia, akcentujące charakter danego naruszenia lub skutki, jakie naruszenie to wywołało; por. B. Adamiak, J. Borkowski, op. cit., s. 874 n. i wskazana tam literatura.

14 C. Banasiński, M. Bychowska, op. cit., s. 50.

15 Tymczasem zakres zastosowania procedury cywilnej w obszarze publicznego prawa gospodarczego stopniowo rośnie - chodzi zwłaszcza o tak zwane procedury hybrydowe w sprawach ochrony konkurencji i regulacji sektorów infrastrukturalnych, w ramach których od decyzji wydanej przez organ stronie (przedsiębiorcy) służy odwołanie do sądu powszechnego, przed którym dalsze postępowanie toczy się na podstawie przepisów k.p.c.; na temat charakteru tych postępowań zob. m.in. B. Popowska, Publiczne prawo gospodarcze w plaszczyźnie proceduralnej, [w:] Nowe problemy badawcze w teorii publicznego prawa gospodarczego (z uwzględnieniem samorzadu terytorialnego), red. L. Kieres, Wrocław 2010, s. 215 n.; M. Chołodecki, Kontrola sq̨dowa decyzji Prezesa Urzędu Komunikacji Elektronicznej, Warszawa 2013, zwł. s. 274 n.; zob. także postanowienie SN z dnia 10 marca 2017 r., III CZP 116/16, Legalis. 
cyjnych $^{16}$. Jej wprowadzenie oznacza, że naruszenie przez organ kontrolujący zasad kontroli w gruncie rzeczy nie skutkuje nieważnością lub bezskutecznością całej kontroli i wszystkich jej wyników ${ }^{17}$. Przeciwnie, może być ono jedynie przesłanką dyskwalifikacji poszczególnych dowodów, i to tylko tych, co do których spełniony jest ów warunek istotnego wpływu na wynik kontroli. W orzecznictwie sądów administracyjnych brakuje jednolitej wykładni przesłanki istotnego wpływu naruszenia na wynik kontroli, niemniej jednak zarysowuje się tendencja do jej interpretowania wedle testu warunku sine qua non $^{18}$. Pozyskany z naruszeniem zasad kontroli dowód tylko wtedy ma istotny wpływ na wynik kontroli, gdy bez tego naruszenia $\mathrm{z}$ całą pewnością dowodu w ogóle nie udałoby się przeprowadzić, a tym samym wynik kontroli byłby inny.

Warto zauważyć, że ustawodawca nie wprowadził żadnych szczególnych unormowań wskazujących, kto (jaki organ, sąd) i w jakim trybie władny jest ustalić, że podczas kontroli przeprowadzono dowód z naruszeniem prawa, lecz także ocenić, czy naruszenie to miało istotny, czy nieistotny, wpływ na wynik kontroli ${ }^{19}$. Problem ten dostrzeżono również w orzecznictwie — zapadały już rozstrzygnięcia, w których brak w ustawodawstwie szczególnego trybu ustalania, że organ w toku kontroli naruszył prawo, uznawano za przeszkodę w zastosowaniu art. 77 ust. 6 usdg $^{20}$. Moim zdaniem stanowisko to nie zasługuje na aprobatę. Trudno bowiem przyjąć, że racjonalny ustawodawca wymagałby kwalifikowanego sposobu stwierdzania zaistnienia przesłanki zastosowania wprowadzanego ograniczenia dowodowego $\mathrm{i}$ jednocześnie nie uregulowałby, kto i w jakim trybie miałby tego stwierdzenia dokonać. Przeciwnie, należy przyjąć, że skoro ustawodawca nie wprowadza żadnego kwalifikowanego sposobu ustalania, że w toku kontroli przedsiębiorcy doszło do naruszenia zasad kontroli, to do dokonania oceny w tym zakresie uprawniony, a nawet zobowiązany jest każdy organ lub sąd, który w postępowaniu administracyjnym, podatkowym, karnym lub karno-skarbowym zamierzałby wydać rozstrzygnięcie na podstawie dowodu przeprowadzonego podczas niezgodnej z przepisami rozdz. 5 usdg kontroli przedsiębiorcy ${ }^{21}$.

16 Zob. m.in. wyrok NSA z dnia 17 listopada 2015 r., I FSK 650/14, Legalis; wyrok WSA w Warszawie z dnia 7 października 2015 r., III SA/Wa 3910/14, Legalis; wyrok NSA z dnia 2 kwietnia 2015 r., I FSK 2053/13, Legalis; wyrok NSA z dnia 9 stycznia 2014 r., II GSK 1433/12, Legalis

17 Zob. wyrok WSA w Olsztynie z dnia 7 listopada 2013 r., I SA/Ol 605/13, Legalis; wyrok WSA we Wrocławiu z dnia 9 grudnia 2010 r., III SA/Wr 562/10, Legalis

18 Np. wyrok NSA z dnia 9 stycznia 2014 r., II GSK 1433/12, Legalis.

19 M. Sieradzka, [w:] M. Zdyb, M. Sieradzka, Ustawa o swobodzie działalności gospodarczej. Komentarz, Warszawa 2013, s. 610.

20 Zob. np. wyrok NSA z dnia 13 lutego 2014 r., II GSK 1923/12, Legalis

21 Podobnie H. Gronkiewicz-Waltz, K. Jaroszyński, op. cit., s. 297. Analogicznie (o czym dalej) skoro art. $417 \S 1$ k.c. nie wymaga istnienia prejudykatu, to należy przyjąć, że do dokonania oceny, czy organ działał niezgodnie z prawem, uprawniony jest sąd w procesie cywilnym o odszkodowanie. 
Pewne rozbieżności w orzecznictwie budzi także kwestia rozkładu ciężaru dowodu — zgodnie z nurtem dominującym ciężar dowodu spoczywa na przedsiębiorcy w pełnym zakresie, to jest powołując się na art. 77 ust. 6 usdg, musi on udowodnić, że 1. w toku kontroli naruszono prawo oraz 2. że naruszenie to miało istotny wpływ na wynik kontroli. Argumentem, jaki ma za tym przemawiać, jest usytuowanie przepisu art 77 ust. 6 bezpośrednio po ust. 4-5, mówiących o odszkodowaniu ${ }^{22}$. Takie ujęcie jest $\mathrm{w}$ mojej ocenie nieuprawnione, ponieważ prowadzić musi do wniosku, że organ, który naruszył prawo, nadal znajduje się w lepszej procesowej sytuacji. W mojej ocenie, jeśli przedsiębiorca udowodni, że w toku kontroli naruszono prawo, wówczas to na organie powinien spoczywać ciężar udowodnienia, że naruszenie nie miało istotnego wpływu na wynik kontroli, a zatem że wynik kontroli byłby tożsamy również wtedy, gdyby przebiegała ona lege artis. Warto odnotować, że tendencja do przerzucenia ciężaru dowodu w tym zakresie na organ pojawiła się w orzecznictwie, jakkolwiek trudno uznać ją za linię ugruntowaną ${ }^{23}$.

Dokonując oceny przepisu art. 77 ust. 6 usdg, można więc postawić tezę, że zawarte w nim ograniczenie dowodowe nie ma charakteru absolutnego i uniwersalnego. $Z$ regulacji tej nie wynika, że wszystkie dowody przeprowadzone w toku kontroli z naruszeniem prawa zostają z mocy prawa zdyskwalifikowane. Z uwagi na wprowadzone w art. 77 ust. 6 ograniczenia nie jest prawdą, że dowód zdobyty w sposób nielegalny nigdy i przeciwko nikomu nie będzie mógł zostać użyty. Dyskwalifikacja dowodu ze względu na jego niezgodne z prawem przeprowadzenie ma jedynie charakter warunkowy. Nadto, przepis art. 77 ust. 6 może wywołać skutek co najwyżej odnośnie do poszczególnego dowodu (dowodów) przeprowadzonych w trakcie kontroli — jego skutek nigdy natomiast nie unieważni całej kontroli ani nie uczyni jej niebyłą ${ }^{24}$.

Jednocześnie unormowanie to ma wiele walorów. Rozszerza ono ochronę praw przedsiębiorcy w ten sposób, że zobowiązuje każdy organ lub sąd, który w postępowaniu administracyjnym, podatkowym, karnym lub karno-skarbowym zamierzałby wydać wobec kontrolowanego przedsiębiorcy rozstrzygnięcie na

22 Por. wyrok NSA z dnia 13 lutego 2014 r., II GSK 1923/12; wyrok NSA z dnia 20 listopada 2012 r., II GSK 1593/11, Legalis.

23 Jak wskazuje NSA, dowody przeprowadzone w toku kontroli z naruszeniem prawa będą mogły być wykorzystane w postępowaniu, pod warunkiem że powyższe uchybienie nie miało istotnego wpłwu na wynik kontroli; por. wyrok NSA z dnia 13 grudnia 2013 r., I FSK 1645/12, Legalis; wyrok NSA z dnia 2 kwietnia 2015 r., I FSK 2053/13. Z kolei w wyroku z 16 grudnia $2011 \mathrm{r}$. (II GSK 1344/10) NSA za nieprawidłowe uznał stanowisko, że „organ musi uzasadnić, że dowody uzyskane z naruszeniem czasu kontroli mogą być wykorzystane we wszczętym postępowaniu administracyjnym".

24 Wyrok NSA z dnia 5 marca 2013 r., II OSK 2111/11; wyrok NSA z dnia 8 marca 2017 r., III SA/Wa 3098/14, Legalis; podobnie wyrok WSA w Opolu z dnia 15 kwietnia 2014 r., II SA/Op 66/14; wyrok NSA z dnia 20 listopada 2012 r., II GSK 1593/11. 
podstawie dowodu przeprowadzonego podczas kontroli tego przedsiębiorcy, do dokonania oceny, czy kontrola ta prowadzona była zgodnie z przepisami usdg. To z kolei pozwala na wyeliminowanie przez organy lub sądy z obrotu prawnego dowodów zdobytych z naruszeniem prawa. Nadto, art. 77 ust. 6 dyscyplinuje organy kontroli, zmuszając je do większej staranności w kwestii zapewnienia, by prowadzona u przedsiębiorcy kontrola przebiegała zgodnie z prawem. Organowi prowadzącemu kontrolę przestaje tym samym „opłacać się” naruszenie zasad kontroli, gdyż uzyskana dzięki temu korzyść (przeprowadzony wskutek tego naruszenia dowód) nie będzie mógł zostać wykorzystany. Jeśli zatem organ zamierza skutecznie realizować swoją funkcję i tym samym chronić interes publiczny, winien zadbać o skuteczność kontroli, tak by przeprowadzone dowody mogły być następnie wykorzystywane $\mathrm{w}$ dalszych postępowaniach dotyczących kontrolowanego przedsiębiorcy.

\section{PRAWO DO ODSZKODOWANIA}

Przechodząc do analizy prawa do odszkodowania, należy odpowiedzieć na pytanie, czy wprowadzając przepisy art. 77 ust. 4-5 usdg, ustawodawca przyznał czy tylko potwierdził prawo przedsiębiorcy do odszkodowania. Trafnie wskazują bowiem C. Banasiński i M. Bychowska, że usdg nie wprowadza nowej, niezależnej podstawy odpowiedzialności odszkodowawczej, ale odsyła do innej regulacji, to znaczy do art. 417 k.c., który obowiązuje niezależnie od nich ${ }^{25}$ oraz któremu w obszarze odpowiedzialności odszkodowawczej państwa przypisuje się walor zasady ogólnej ${ }^{26}$. Co więcej, zarówno w doktrynie, jak i w orzecznictwie wskazuje się na szerokie rozumienie art. 417 k.c. (za którego przyjęciem przemawia także wzgląd na treść art. 77 ust. 1 Konstytucji $\mathrm{RP}^{27}$ ), który traktuje o konsekwencjach wykonywania władzy publicznej, przez co należy rozumieć co najmniej wszelkie działania lub zaniechania organów państwa i ich funkcjonariuszy, w tym działania faktyczne ${ }^{28}$,

25 C. Banasiński, M. Bychowska, op. cit., s. 49.

26 R. Szczepaniak, [w:] Kodeks cywilny, t. 1. Komentarz, red. M. Gutowski, Warszawa 2016, s. 1595 .

27 Trybunał Konstytucyjny w wyroku z dnia 1 września 2006 r. (SK 14/05, OTK-A 2006, nr 8, poz. 97) wskazał, że art. 77 ust. 1 Konstytucji RP jest źródłem prawa podmiotowego do domagania się odszkodowania za niezgodne z prawem działania władzy publicznej; zob. P. Sobolewski, [w:] Kodeks cywilny. Komentarz. Zobowiązania. Część ogólna, red. K. Osajda, Warszawa 2017, s. 545.

28 G. Bieniek, [w:] G. Bieniek et. al., Komentarz do kodeksu cywilnego, ks. 3. Zobowiazania, t. 1, Warszawa 2009, s. 331, 348. A contrario do art. 417(1) k.c., regulującego w sposób szczególny do art. 417 k.c. odpowiedzialność odszkodowawczą za wybrane działania władcze o charakterze prawnym, w szczególności wydanie aktu normatywnego, prawomocnego orzeczenia lub ostatecznej decyzji. 
mieszczące się w sferze imperium ${ }^{29}$. Okoliczności, że organ o przeprowadzeniu kontroli (ale też o jej zakresie) rozstrzyga jednostronnie, prowadzi ją na podstawie i w granicach upoważnienia, ma prawo wstępu na teren prowadzonej działalności czy pobierania próbek, a przedsiębiorca obowiązany jest do prowadzenia i przechowywania książki kontroli, w której wpisy dokonywane są również przez organ kontroli, a zebrane przez organ dowody mogą służyć jako podstawa nie tylko do wydania wiążących przedsiębiorcę zaleceń pokontrolnych ${ }^{30}$, lecz także jako dowody w rozmaitych późniejszych postępowaniach (zmierzających na przykład do nałożenia kary pieniężnej, cofnięcia koncesji czy wydania decyzji o zakazie wykonywania działalności regulowanej), prowadzonych w ramach wykonywania przez organ swych funkcji władczych, pozwalają zakwalifikować czynności kontrolne organu u przedsiębiorcy do sfery imperium. W konsekwencji czynności te należy traktować jako wykonywanie władzy publicznej w rozumieniu art. 417 k.c. ${ }^{31}$ To z kolei skłania do wniosku o słuszności twierdzenia, że przez wprowadzenie art. 77 ust. 4-5 usdg ustawodawca nie przyznał, lecz jedynie potwierdził prawo przedsiębiorcy do odszkodowania za szkodę wynikłą z prowadzenia kontroli z naruszeniem prawa.

Na obronę ustawodawcy podnieść można jedynie, że zgodnie ze stanowiskiem doktryny i judykatury kontrola przedsiębiorcy nie jest sama w sobie postępowa-

29 W. Dubis, J. Kremis, [w:] Kodeks cywilny. Komentarz, red. E. Gniewek, P. Machnikowski, Warszawa 2017, s. 830; G. Bieniek, op. cit., s. 336. W sferze dominium odpowiedzialność oparta jest natomiast na zasadach ogólnych, właściwych innym osobom fizycznym i prawnym (np. art. 416, 427, 429, 430 k.c.); wyrok Sądu Apelacyjnego w Katowicach z dnia 12 października 2006 r., I ACa 838/06, OSA 2007, nr 1, poz. 5; szerzej na temat wątpliwości co do sposobu rozumienia terminu ,wykonywanie władzy publicznej” z art. 417 k.c., zwłaszcza w wypadkach gdy organ działa w formach niewładczych, por. R. Szczepaniak, op. cit., s. 1611 n. i wskazana tam literatura - autor również przyznaje jednak, że kwalifikacja danego działania organu do sfery imperium implikuje zasadność zastosowania art. 77 ust. 1 Konstytucji i art. 417 k.c.; por. też wyrok TK z dnia 4 grudnia 2001 r., SK 18/00, OTK 2001, nr 8, poz. 256.

30 W kwestii charakteru prawnego zaleceń pokontrolnych por. wyrok WSA w Opolu z dnia 25 marca 2008 r., II SA/Op/5/08; a także postanowienia NSA z dnia 6 lutego 2008 r., II OSK 107/08; oraz z dnia 28 lutego 2008 r., II OSK 216/08, opublikowane w Centralnej Bazie Orzeczeń Sądów Administracyjnych.

31 Trybunał, analizując z kolei pojęcie wykonywania władzy publicznej zawarte w art. 77 ust. 1 Konstytucji RP, wskazał, że ,wykonywanie władzy publicznej dotyczy wszelkich form działalności państwa, samorządu terytorialnego i innych instytucji publicznych, które obejmują bardzo zróżnicowane formy aktywności. Wykonywanie takich funkcji łączy się z reguły, chociaż nie zawsze, z możliwością władczego kształtowania sytuacji jednostki. Dotyczy to obszaru, na którym może dojść do naruszenia praw i wolności jednostki ze strony władzy publicznej. Nazwa »organ« władzy publicznej, użyta w art. 77 ust. 1 Konstytucji, oznacza instytucję, strukturę organizacyjną, jednostkę władzy publicznej, z której działalnością wiąże się wyrządzenie szkody, nie zaś organ osoby prawnej w kategoriach prawa cywilnego", wyrok TK z dnia 4 grudnia 2001 r., SK 18/00, OTK ZU 2001, nr 8, poz. 256, s. 1342. 
niem administracyjnym (jurysdykcyjnym ${ }^{32}$ ) w rozumieniu art. 1 k.p.a. ${ }^{33} \mathrm{Z}$ tego względu mogą powstawać wątpliwości, czy czynności kontrolne wykonywane przez organ kontroli rzeczywiście mieszczą się w zakresie wykonywania władzy publicznej, o którym mowa w art. 417 k.c. Po wprowadzeniu art. 77 ust. 4-5 usdg ustawodawca rozwiewa tę niejasność, jednoznacznie potwierdzając prawo do odszkodowania. Ponadto mamy tu do czynienia z regulacją wyrażającą prawo przedsiębiorcy, zawartą $\mathrm{w}$ ustawie mającej kompleksowo normować podejmowanie, wykonywanie i zakończenie działalności gospodarczej oraz zadania organów w tym zakresie (art. 1 usdg). Jakkolwiek zgadzam się z C. Banasińskim i M. Bychowską, że zamieszczanie w tekście prawnym tego rodzaju „przypomnień” jest wątpliwe legislacyjnie ${ }^{34}$, to jednak ma pewne uzasadnienie w celach i zakresie ustawy.

Odpowiedzialność na podstawie art. 417 k.c. jest odpowiedzialnością za czyn niedozwolony (delikt władzy publicznej), którego dopuścił się organ ${ }^{35}$. Oznacza to, że do uzyskania odszkodowania konieczne będzie udowodnienie przez przedsiębiorcę (na którym zgodnie z art. 6 k.c. spoczywa w tym zakresie ciężar dowodu) łącznie trzech przesłanek: niezgodności z prawem działania lub zaniechania organu ${ }^{36}$, szkody ${ }^{37}$ oraz związku przyczynowego między

32 To jest postępowaniem, którego przedmiotem jest autorytatywna konkretyzacja normy prawa materialnego dotyczącej uprawnienia lub obowiązku obywatela w formie decyzji administracyjnej (postępowanie jurysdykcyjne); por. B. Adamiak, Koncepcja postępowania administracyjnego, [w:] System Prawa Admisnitracyjnego, t. 9. Prawo procesowe administracyjne, red. B. Adamiak, J. Borkowski, Warszawa 2014, s. 3 i 8.

33 W. Chróścielewski, Glosa do uchwaty NSA z dnia 13 stycznia 2014 r., II GPS 3/13, „Orzecznictwo Sądów Polskich" 2014, nr 7-8, s. 69; por. np. postanowienie NSA z dnia 14 września 2012 r., II GSK 1431/12; postanowienie WSA w Łodzi z dnia 10 kwietnia 2015 r., I SA/Ld 350/15; wyrok WSA w Gliwicach z dnia 18 czerwca 2013 r., IV SA/G1 1082/12; postanowienie NSA z dnia 12 grudnia 2012 r., II OSK 2911/12; zob. także uzasadnienie uchwały składu siedmiu sędziów NSA z dnia 13 stycznia 2014 r., II GPS 3/13.

34 C. Banasiński, M. Bychowska, op. cit., s. 49.

$35 \mathrm{~W}$ praktyce najczęściej jest to jego funkcjonariusz, nie ma natomiast znaczenia formalny status osoby będącej sprawcą szkody, lecz charakter i rodzaj podejmowanych przez nią czynności jako mieszczących się w obszarze kompetencji danej instytucji; tak G. Bieniek, op. cit., s. 354.

$36 \mathrm{~W}$ doktrynie wyróżnia się co najmniej dwa sposoby ustalania tej niezgodności: węższy, wymagający stwierdzenia naruszenia przez organ konkretnej normy prawnej (materialnej lub procesowej), oraz szerszy, obejmujący także naruszenie zasad współzycia społecznego; por. W. Dubis, J. Kremis, op. cit., s. 833 i wskazana tam literatura; G. Bieniek, op. cit., s. 349. Bez względu na przyjęte stanowisko naruszenie zasady kontroli ujętych w przepisach usdg będzie wypełniało przesłankę bezprawności.

37 Którą może być nie tylko szkoda rzeczywista czy utracone korzyści (art. 361 § 2 k.c.; wyrok SN z dnia 18 stycznia 2002 r., I CKN 132/01, Legalis), lecz także tak zwana szkoda niemajątkowa, czyli krzywda, której naprawienie następuje na drodze zadośćuczynienia (art. 445, 448 k.c.; zob. też uzasadnienie uchwały składu siedmiu sędziów SN z dnia 18 października 2011 r., III CZP 25/11, OSNC 2012, nr 2, poz. 15); por. W. Dubis, J. Kremis, op. cit., s. 840. Zasadne wydaje się twierdzenie, że na gruncie art. 417 § 1 k.c. dochodzić można rekompensaty za szkody wynikające z samych czynności kontrolnych, wykonywanych niezgodnie z prawem — jeśli natomiast szkoda wynika z decyzji 
nimi $^{38}$. Nie jest natomiast konieczne wykazanie, że do deliktu doszło z winy organu $^{39}$. Oznacza to, że ustawodawca odstępuje w tym wypadku od dominującej w obszarze odpowiedzialności deliktowej zasady winy na rzecz odpowiedzialności na zasadzie obiektywnej niezgodności z prawem ${ }^{40}$. Niezgodność z prawem, o której mowa w art. 417 k.c., nie jest elementem stosunku prywatnoprawnego, ale stosunku publicznoprawnego (w tym przypadku między kontrolowanym przedsiębiorcą a organem kontroli), a w konsekwencji musi być ustalana na podstawie norm regulujących dany stosunek publicznoprawny ${ }^{41}$ (w interesującym nas wypadku będą to przepisy ustawy szczególnej regulującej zakres przedmiotowy kontroli i kompetencje organu kontroli oraz przepisy rozdz. 5 usdg). Co jednak istotne, w odróżnieniu od art. 417 (1) k.c. art. 417 k.c. nie wprowadza kwalifikowanego sposobu stwierdzania niezgodności z prawem działania organu ${ }^{42}$, to znaczy nie wymaga wydania uprzedniego prejudykatu we właściwym postępowaniu (na przykład sądowoadministracyjnym) — niezgodność z prawem zachowania organu kontroli, podobnie jak istnienie innych przesłanek odpowiedzialności odszkodowawczej (szkoda, związek przyczynowy), ustala zatem sąd w procesie cywilnym o odszkodowanie ${ }^{43}$. Z tego samego względu należy także wyrazić pogląd, że prawo do odszkodowania za szkodę wynikłą z prowadzenia kontroli z naruszeniem zasad nie jest uwarunkowane wcześniejszym skorzystaniem przez przedsiębiorcę z instytucji sprzeciwu wobec czynności kontrolnych, unormowanej w art. 84c usdg. Po pierwsze, warunek taki nie wynika ani z przepisów usdg, ani kodeksu cywilnego. Po drugie, niewniesienie sprzeciwu nie może samo w sobie legalizować wyników kontroli prowadzonej z naruszeniem prawa czy przeprowadzonych w toku takiej kontroli dowodów. Przemawia za tym wreszcie także bardzo krótki, trzydniowy, termin na jego wniesienie (art. 84c ust. 3 usdg). Dlatego też do wytoczenia powództwa wystarczy samo przekonanie przedsiębiorcy, że w toku kontroli doszło do naruszenia prawa skutkującego szkodą, a powództwo okaże się zasadne, jeśli przedsiębiorca wykaże wszystkie wskazane przesłanki odpowiedzialności.

wydanej na podstawie wadliwie przeprowadzonych podczas kontroli dowodów, to odszkodowania $\mathrm{z}$ tego tytułu przedsiębiorca dochodzić powinien na podstawie art. 417 (1) § 2 k.c.

38 Zgodnie z art. 361 § 1 k.c. związek przyczynowy winien być normalny (adekwatny), co nie oznacza bynajmniej, że musi być bezpośredni — przy ustalaniu istnienia związku przyczynowego na użytek zastosowania art. 417 k.c. należy brać pod uwagę cel działania organu; tak G. Bieniek, op. cit., s. 351.

39 W. Dubis, J. Kremis, op. cit., s. 829, 839; G. Bieniek, op. cit., s. 353; P. Sobolewski, op. cit., s. 545 .

$40 \mathrm{Na}$ temat różnicy między niezgodnością z prawem działania organu a bezprawnością por. P. Sobolewski, op. cit., s. 553 n. i wskazana tam literatura.

41 Wyrok SA w Poznaniu z dnia 27 września 2012 r., I ACa 678/12, Legalis; wyrok SA w Łodzi z dnia 7 sierpnia 2013 r., I ACa 311/13, Legalis; szerzej na temat rozumienia bezprawności w kontekście odpowiedzialności odszkodowawczej państwa zob. R. Szczepaniak, op. cit., s. 1616 n.

42 Wyrok SA w Katowicach z dnia 24 kwietnia 2013 r., I ACa 193/13, Legalis.

43 W. Piątek, A. Skoczylas, op. cit., s. 171; W. Chróścielewski, op. cit., s. 935. 


\section{WNIOSKI KOŃCOWE}

Tytułem podsumowania wypada zauważyć, że zarówno ograniczenia co do możliwości wykorzystania uzyskanych dowodów, jak i prawo przedsiębiorcy do dochodzenia odszkodowania, jakkolwiek całkowicie niezależne od siebie (niewarunkujące się nawzajem), tworzą funkcjonalną całość. Obie regulacje pełnią funkcję ochronną wobec praw przedsiębiorcy ${ }^{44}$. Jednocześnie skłaniają organ kontroli do szczególnej dbałości, aby prowadzona kontrola przebiegała zgodnie z prawem, a to ze względu na interes publiczny, przejawiający się nie tylko w potrzebie zabezpieczenia prawnej skuteczności przeprowadzonych podczas kontroli dowodów, lecz także w dążeniu do uniknięcia odpowiedzialności odszkodowawczej państwa.

$\mathrm{O}$ ile instytucja prawa do odszkodowania za niezgodne z prawem działania lub zaniechania władzy publicznej jest znana prawu cywilnemu, o tyle ograniczenia dowodowe wynikające $\mathrm{z}$ art. 77 ust. 6 usdg są rozwiązaniem swoistym, właściwym tylko kontroli przedsiębiorcy, dla których próżno aktualnie szukać bezpośrednich odpowiedników w procedurze administracyjnej, cywilnej czy karnej. Ograniczenia te można zatem postrzegać jako realizację konstytucyjnie gwarantowanej przedsiębiorcom wolności gospodarczej, ale też wynikających z niej dalszych zasad kształtujących relacje administracji gospodarczej z przedsiębiorcami, takich jak zasada wspierania rozwoju przedsiębiorczości i tworzenia korzystnych warunków do wykonywania działalności gospodarczej (art. 8 ust. 1 usdg), zasada wykonywania przez organy swych zadań na podstawie i w granicach prawa z poszanowaniem uzasadnionych interesów przedsiębiorcy (art. 9 usdg) czy wreszcie zasada sprawiedliwości proceduralnej ${ }^{45}$. Są one także ujmowane jako konkretyzacja zasady budowania zaufania obywateli, w tym przedsiębiorców, do państwa i jego organów ${ }^{46}$.

Regulacja prawna zarówno zasad kontroli, jak i prawnych konsekwencji prowadzenia kontroli z ich naruszeniem zdaje się mieć utrwalone miejsce w przepisach publicznego prawa gospodarczego. Świadczy o tym treść projektu ustawy Prawo przedsiębiorców ${ }^{47}$, która ma zastąpić usdg i która zachowuje niemal w całości regulację prawną dotychczasowego rozdz. 5 usdg, w tym zwłaszcza katalog zasad kontroli czy instytucję sprzeciwu od czynności kontrolnych. W projekcie nowej ustawy interesujący nas rozdział zatytułowano w mojej ocenie bardziej adekwatnie do jego treści - Ograniczenia kontroli wykonywania działalności

44 C. Kosikowski, Ustawa o swobodzie działalności gospodarczej. Komentarz, Warszawa 2013, s. 506.

45 Szerzej zob. M. Strzelbicki, Zasada sprawiedliwości proceduralnej w procedurach publicznego prawa gospodarczego, [w:] Swoistość procedur publicznego prawa gospodarczego, red. B. Popowska, Poznań 2013, s. 75 n.

46 H. Gronkiewicz-Waltz, K. Jaroszyński, [w:] Prawo gospodarcze. Zagadnienia administracyjnoprawne, red. H. Gronkiewicz-Waltz, M. Wierzbowski,Warszawa 2011, s. 295-296.

47 Sejm RP VIII kadencja, druk nr 2051, http://orka.sejm.gov.pl/Druki8ka.nsf/0/9E761CF9B 6B03CBCC12581E10059DD88/\%24File/2051.pdf (dostęp: 18.01.2018). 
gospodarczej. Regulację zawartą dotąd w art. 77 ust. 4-5 usdg (prawo do odszkodowania) oraz art. 77 ust. 6 usdg (ograniczenia dowodowe) projektodawca ujmuje w odrębnej jednostce redakcyjnej (art. 45 projektu ustawy). Również ten zabieg należy ocenić pozytywnie - nie tylko zwiększa on przejrzystość regulacji, ale też podkreśla tożsamy charakter prawa do odszkodowania i ograniczeń dowodowych jako prawnych konsekwencji prowadzenia przez organ kontroli działalności gospodarczej przedsiębiorcy z naruszeniem zasad kontroli.

\title{
LEGAL CONSEQUENCES OF ENTREPRENEUR INSPECTION CONDUCTED IN VIOLATION OF PRINCIPLES FOR INSPECTION
}

\author{
Summary
}

With the enforcement of the Business Activities Freedom Act, the provisions of Chapter 5 entitled "Entrepreneur Inspection" have become to apply in the Polish Public Economic Law. The essence of the regulation lies in the principles for inspection, namely standards to be met by each and every entrepreneur's business inspection performed by administrative bodies. Legal regulation of entrepreneur inspection, providing for legal framework of the procedure and setting limits to the actions of the inspection authority, was aimed by the legislator to limit the natural advantage of the authority over the entrepreneur during the inspection proceeding.

The legislator was aware that the very introduction of principles for inspection would not be sufficient to effectively protect entrepreneurs' interests. For this reason, the administrative authorities have been obliged to apply the principles for trader inspection through far-reaching negative legal consequences to the authority in the event of breach. The article analyses such legal solutions which provide entrepreneurs with the right to pursue compensation from the state, and permit demanding that the evidence gathered during the inspection could not be used against such trader by the administration authorities (the "fruit of the poisonous tree" principle). The author presents the scope of application of both such instruments, and takes a stand as regards related detailed issues which have so far been the bone of contention both in the doctrine and in the judgements.

Keywords: entrepreneur inspection, principles for entrepreneur's business inspection, liability of the state, the "fruit of the poisonous tree" principle, limitations to use of illegally obtained evidence

\section{BIBLIOGRAFIA}

Adamiak B., Borkowski J., Kodeks postępowania administracyjnego. Komentarz, Warszawa 2017. Banasiński C., Bychowska M., Kontrola przedsiębiorcy w świetle ustawy o swobodzie działalności gospodarczej, „Przegląd Prawa Handlowego” 2010, nr 1.

Bieniek G. et al., Komentarz do kodeksu cywilnego, ks. 3. Zobowiazania, t. 1, Warszawa 2009.

Chołodecki M., Kontrola sądowa decyzji Prezesa Urzędu Komunikacji Elektronicznej, Warszawa 2013.

Chróścielewski W., Glosa do uchwały NSA z dnia 13 stycznia 2014 r., II GPS 3/13, „Orzecznictwo Sądów Polskich” 2014, nr 7-8. 
Hibner W., Czy w polskim systemie prawnym obowiazuje zasada pozyskiwania dowodów z „owoców zatrutego drzewa”?, „Homines Hominibus” 2011, nr 7.

Kiczka K., Wprowadzenie, „Przegląd Prawa i Administracji” 98, 2014.

Kieres L., Wprowadzenie, [w:] Środki publicznego prawa gospodarczego, red. L. Kieres, Wrocław 2007.

Kodeks cywilny, t. 1. Komentarz, red. M. Gutowski, Warszawa 2016.

Kodeks cywilny. Komentarz, red. E. Gniewek, P. Machnikowski, Warszawa 2017.

Kodeks cywilny. Komentarz. Zobowiązania. Część ogólna, red. K. Osajda, Warszawa 2017.

Kosikowski C., Ustawa o swobodzie działalności gospodarczej. Komentarz, Warszawa 2013.

Lech P., Owoce zatrutego drzewa w procesie karnym. Dowody zdobyte nielegalnie, „Palestra” 2012, nr 3-4.

Lewandowski M., Koncepcja „owoców zatrutego drzewa” a swobodna ocena dowodów w orzecznictwie sąów polskich i Europejskiego Trybunału Praw Człowieka, „Studia Prawa Publicznego" 2013, nr 2.

Popowska B., Dedykacje i wspomnienia, [w:] Funkcje wspótczesnej admisnitracji gospodarczej. Księga dedykowana Profesor Teresie Rabskiej, red. B. Popowska, Poznań 2006.

Popowska B., Publiczne prawo gospodarcze w płaszczyźnie proceduralnej, [w:] Nowe problemy badawcze $w$ teorii publicznego prawa gospodarczego ( $z$ uwzględnieniem samorzadu terytorialnego), red. L. Kieres, Wrocław 2010.

Prawo gospodarcze. Zagadnienia administracyjnoprawne, red. H. Gronkiewicz-Waltz, M. Wierzbowski, Warszawa 2011.

Strzelbicki M., Zasada sprawiedliwości proceduralnej w procedurach publicznego prawa gospodarczego, [w:] Swoistość procedur publicznego prawa gospodarczego, red. B. Popowska, Poznań 2013.

System Prawa Administracyjnego, t. 9. Prawo procesowe administracyjne, red. B. Adamiak, J. Borkowski, Warszawa 2014. 